\title{
Sagittal and vertical aspects of Class II division 1 subjects according to the respiratory pattern
}

Laura de Castro Cabrera', Luciana Borges Retamoso², Raul Magnoler Sampaio Mei ${ }^{3}$, Orlando Tanaka ${ }^{4}$

Introduction: The teeth position, specially maxillary and mandibular incisors, in relation to basal bone and surrounding soft tissues must be considered in the elaboration of diagnosis, treatment planning and execution to obtain alignment, leveling, intercuspation, facial balance and harmony with stability of results. Objectives: To evaluate the modifications in the positioning of incisors in individuals with Angle Class II, division 1 malocclusion in two distinct moments of dentocraniofacial development, with mean interval of 2 years and 5 months. Methods: The measures were obtained by means of lateral cephalograms of 40 individuals, being 23 nasal breathers (NB) and 17 mouth breathers (MB). The analyzed measures were overjet, overbite, UCI-NA, LCI-NB, UCI.NA, LCI.NB, UCI.SN, LCI.GoGn, UCI.LCI, ANB, GoGn.SN, and OccPl.SN. Statistical analysis (2-way repeated-measures ANOVA) was applied to verify intergroups differences. Results: Overjet, UCI-NA, LCI-NB, ANB, GoGn.SN, and OccPl.SN demonstrated statistically significant difference $(\mathrm{p}<0.05)$ when observed the moment or the respiratory method. Conclusion: There is alteration in the positioning of incisors during growth with interference of the respiratory pattern.

Keywords: Angle Class II malocclusion. Mouth breathing. Breathing. Vertical dimension.

Introdução: a posição dos dentes, principalmente incisivos superiores e inferiores, em relação às bases ósseas e tecidos moles circundantes deve ser considerada na elaboração do diagnóstico, planejamento e execução do tratamento, para se obter alinhamento, nivelamento, intercuspidação, equilíbrio e harmonia facial com estabilidade dos resultados. Objetivos: avaliar as modificações no posicionamento dos incisivos em indivíduos com má oclusão de Classe II, divisão 1, de Angle, em dois momentos distintos do desenvolvimento dentocraniofacial, num intervalo médio de 2 anos e 5 meses. Métodos: as medidas foram obtidas por meio de telerradiografias em norma lateral de 40 indivíduos, sendo 23 respiradores predominantes nasais $(\mathrm{RN})$ e 17 predominantemente bucais $(\mathrm{RB})$. As medidas avaliadas foram sobressaliência, sobremordida, ICS-NA, ICI-NB, ICS.NA, ICI.NB, ICS.SN, ICI.GoGn, ICS.ICI, ANB, GoGn.SN, Plo.SN. Para verificar a diferença intergrupos, utilizou-se a ANOVA a dois critérios com medidas repetidas. Resultados: sobressaliência, ICS-NA, ICI-NB, ANB, GoGn.SN, Plo.SN apresentaram diferença estatisticamente significativa $(\mathrm{p}<0,05)$ quando observado o momento ou o modo respiratório. Conclusão: existe alteração no posicionamento dos incisivos no decorrer do crescimento, com interferência do modo respiratório.

Palavras-chave: Má oclusão Classe II de Angle. Respiração bucal. Respiração. Dimensão vertical.

${ }^{1} \mathrm{MSc}$ Student in Dentistry.

${ }^{2} \mathrm{PhD}$ Student in Dental Materials, PUCPR.

${ }^{3} \mathrm{MSc}$ in Orthodontics, PUCPR.

${ }^{4}$ Responsible for the area of concentration in Orthodontics of PPGO-PUCPR.

» The authors report no commercial, proprietary or financial interest in the products or companies described in this article.
How to cite this article: Cabrera LC, Retamoso LB, Mei RMS, Tanaka O. Sagittal and vertical aspects of Class II division 1 subjects according to the respiratory pattern. Dental Press J Orthod. 2013 Mar-Apr;18(2):30-5.

Submitted: December 22, 2008 - Revised and accepted: June 08, 2009

Contact address: Orlando Tanaka

Rua Imaculada Conceição, 1155

CEP: 80.215-901 - Curitiba / PR, Brazil

Email: tanakaom@gmail.com 


\section{INTRODUCTION}

Overbite is the vertical trespass and overjet is the horizontal trespass, which suffer significant alterations during development of dentition, from initial mixed dentition to permanent occlusion. ${ }^{16}$ Overbite is correlated to other measures that indicate facial dimensions, such as mandibular plane and occlusal plane angles. Overjet usually is a reflex of the anteroposterior skeletal relation, ${ }^{8}$ and it is sensible to the atypical function of lips and tongue. On the development of Class II and III malocclusions, these dental measurements tend to adapt to abnormal skeletal relations. The position of maxillary and mandibular incisors, the relation between both and to the surrounding tissues, are important characteristics in the diagnosis, execution and stability of the treatment. The measures related to positioning of incisors affect the balance and harmony of facial profile. Due to its importance, since the introduction of craniometry, the position of mandibular incisor on sagittal plane became a precious tool to assess a malocclusion. ${ }^{3,7}$ The determination of positioning of maxillary and mandibular incisor is part of most cephalometric analysis. ${ }^{4}$ Downs ${ }^{6}$ and Riedel ${ }^{19}$ advocated specific values for the position of mandibular incisor, however, other values were suggested and used to predict the stability of the treatment results..$^{22,25,26}$ The maxillary incisors perform an important role because they provide the inclination for protrusive mandibular movement. ${ }^{20}$ Also, the position and specially the axial inclination of maxillary and mandibular incisors, are determinative on facial esthetics, as incisors with increased axial inclinations, create protruded lips and, many times, absence of passive lip seal. The orthodontic treatment is frequently performed during adolescence, between 10 and 16 years of age. ${ }^{17}$ Consequently, the evaluation of incisors positioning, its relation to adjacent structures, overjet and overbite during this period may provide information and contribute to the elaboration of diagnosis, planning, treatment and assessment of the post treatment stability. Thus, this work aims to assess the alterations on the position of maxillary and mandibular incisors in individuals with Angle Class II malocclusion, division 1, in two distinct moments of the dentocraniofacial development, with mean interval of 2 years and 5 months according to respiratory pattern.

\section{MATERIAL AND METHODS}

To perform this research it was used lateral cephalograms of 40 individuals with Angle Class II division 1 malocclusion, where 23 were nasal breathers $(\mathrm{NB})$ and 17 mouth breathers $(\mathrm{MB})$, aged between 10 years and 9 months and 14 years $\left(\mathrm{T}_{1}\right)$, and between 13 years and 4 months and 16 years and 6 months $\left(\mathrm{T}_{2}\right)$. The classification of respiratory pattern was done according to protocol described by Wieler et al, ${ }^{27}$ which includes clinical evaluation of lip seal performed by dental surgeon, survey answered by the parents regarding respiratory habits, otorhinolaryngological assessment and speech evaluation. From these evaluations it was assigned scores and weighting for each evaluation, creating an index to classify the individual's predominant respiratory pattern. On each cephalogram it was fixed a sheet of acetate paper, $50 \mu \mathrm{m}$ thick and $18 \mathrm{~cm}$ high $\times 17 \mathrm{~cm}$ wide. The cephalograms were traced with mechanical pencil Pentel P203 and graphite $2 \mathrm{~B}, 0,3 \mathrm{~mm}$ of diameter, considering the interesting anatomic structures, and only on the left side, by a single operator, in a darkened room, being the only source of light the one from the negatoscope. The linear measures were performed with a single ruler with precision of $0.5 \mathrm{~mm}$, and the angular measures with a protractor, precision of 0.5 degrees. The used angular and linear measures were the following, showed in Figure 1:

1. Overjet: Distance from vestibular surface of mandibular central incisor to palatine surface of maxillary central incisor, in millimeters.

2. Overbite: Distance, in millimeters, that the maxillary central incisor trespass the mandibular central incisor.

3. UCI-NA: Distance, in millimeters, from the vestibular surface of maxillary central incisor to the NA line.

4. LCI-NB: Distance, in millimeters, from the vestibular surface of mandibular central incisor to the NB line.

5. UCI.NA: Angle, measured in degrees, formed by the intersection of the long axis of maxillary central incisor and the NA line.

6. LCI.NB: Angle, measured in degrees, formed by the intersection of the long axis of mandibular central incisor and the NB line.

7. UCI.SN: Angle, measured in degrees, formed by the intersection of the long axis of maxillary central incisor and the $\mathrm{SN}$ line. 


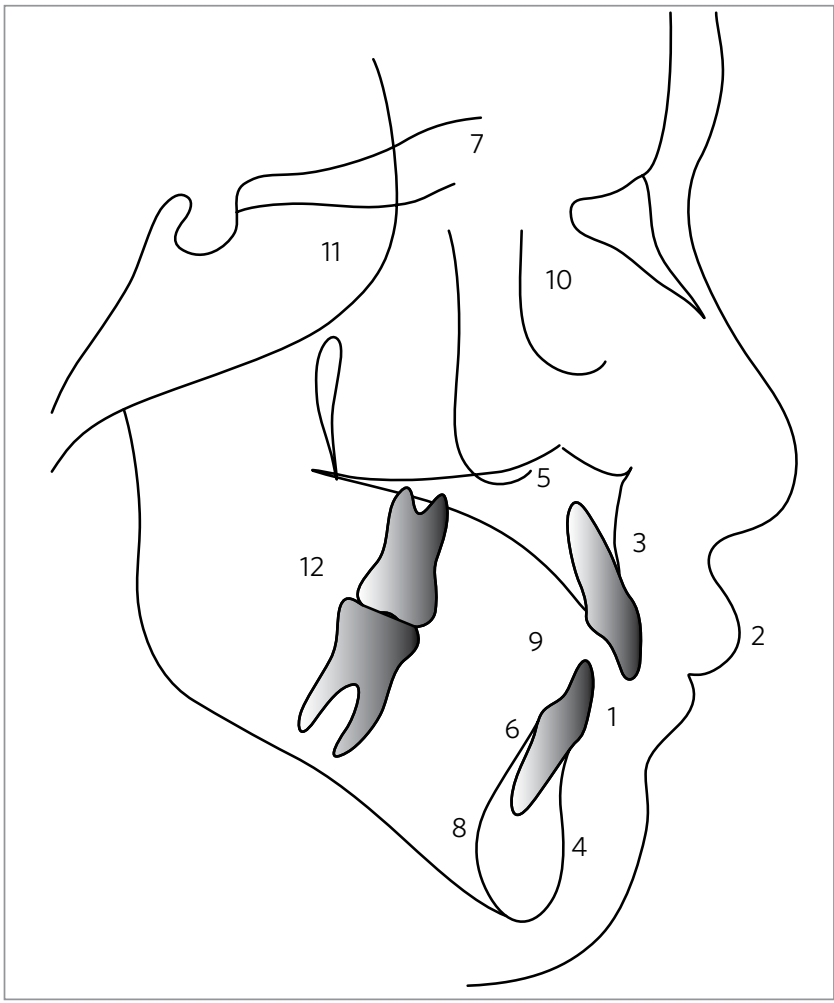

Figure 1 - Linear and angular measurements used.

8. LCI.GoGn: Angle, measured in degrees, formed by the intersection of the long axis of mandibular central incisor and the mandibular plane.

9. UCI.LCI: Angle, measured in degrees, formed by the intersection of the long axis of maxillary central incisor and the long axis of mandibular central incisor.

10. ANB: Difference, measured in degrees, between the angles SNA and SNB, determines the position of the maxilla and mandible in the anteroposterior direction.

11. GoGn.SN: Angle, measured in degrees, that determines the facial pattern in vertical direction.

12. OccPl.SN: Angle, measured in degrees, that determines the inclination of occlusal plane in relation to SN line.

\section{STUDY'S REPRODUCIBILITY ERROR}

To evaluate the reproducibility error, it was randomly selected 30 teleradiographs and a single operator performed the cephalometric evaluation for the second time, with interval of 30 days. It was calculated the systematic error ${ }^{5}$ between the two evaluations and it was observed that, for all the studied measures, this did not exceed 3\%, thus obtaining reliability for all obtained data.

\section{RESULTS}

The statistical analysis was performed using the Statistical Package for the Social Science 15.0 for Windows (SPSS, Inc., Chicago, IL, USA). The verification of normality was performed through Kolmogorov-Smirnov test, at significance level of 0.05 . Once it was found the normal distribution, the verification of existence or absence of difference between the means (Table 1) of the two types of breathers for each one of the two moments, was performed with the aid of ANOVA with two criteria for classification, with repeated measures.

When ANOVA demonstrated that there was a statistically significant difference $(\mathrm{p}<0.05)$ between the mean values of overjet, UCI-NA, LCI-NB, ANB, GoGn.SN and OccPl.SN according to moment or respiratory pattern, it was used Tukey's HSD test of multiple comparison to identify which groups were different from one another (Table 2).

\section{DISCUSSION}

The results of the present work showed that there were alterations on the measures related to positioning of incisors according to moments and respiratory pattern, agreeing with Ceylan et al. ${ }^{4}$ It was observed reduction of the overjet from $\mathrm{T}_{1}$ to $\mathrm{T}_{2}$ in both analyzed groups of individuals (nasal and mouth breathers). This behavior occurs because of the mandibular growth that tends to reduce the facial convexity and the overjet, according to proved studies by Ceylan et al. ${ }^{4}$ Besides, the modification in the positioning of incisors may also have caused the reduction of overjet, for the measure LCI-NB increased in larger proportion than the UCI-NA. Another factor to be considered, is the reduction of the occlusal plane, probably caused by the counterclockwise rotation of the mandible, and consequently reduction of overjet. It is emphasized that the respiratory pattern affected this measure, since mouth breathers present greater overjet than nasal breathers, according to Mocellin ${ }^{15}$ and Ricketts, ${ }^{18}$ who point the respiratory pattern as an etiologic factor for malocclusions. Generally, mouth breathing patients tend to present a protruded maxilla and maxillary atresia, consequence of the alteration on the tongue position, which becomes lower, breaking the 
Table 1 - Mean and standard deviation of linear and angular measures.

\begin{tabular}{|c|c|c|c|c|c|c|c|c|c|}
\hline MEASURE & GROUP & $n$ & MEAN & S.D. & MEASURE & GROUP & n & MEAN & S.D. \\
\hline \multirow{4}{*}{ Overjet } & $\mathrm{NB} \mathrm{T}_{1}$ & 23 & 4.21 & 2.14 & \multirow{4}{*}{ UCI.SN } & $\mathrm{NB}_{1}$ & 23 & 75.96 & 5.18 \\
\hline & $\mathrm{NB} \mathrm{T}_{2}$ & 23 & 3.74 & 1.77 & & $\mathrm{NB}_{2}$ & 23 & 74.96 & 5.53 \\
\hline & $\mathrm{MB} \mathrm{T}_{1}$ & 17 & 5.35 & 1.86 & & $\mathrm{MB} \mathrm{T}_{1}$ & 17 & 75.71 & 5.82 \\
\hline & $\mathrm{MB} \mathrm{T}_{2}$ & 17 & 5 & 1.7 & & $\mathrm{MB} \mathrm{T}_{2}$ & 17 & 74.59 & 5.29 \\
\hline \multirow{4}{*}{ Overbite } & $\mathrm{NB} \mathrm{T}_{1}$ & 23 & 3.26 & 2.18 & \multirow{4}{*}{ LCI.GoGn } & $\mathrm{NB} \mathrm{T}_{1}$ & 23 & 98.78 & 4.23 \\
\hline & $\mathrm{NB} \mathrm{T}_{2}$ & 23 & 3.35 & 1.7 & & $\mathrm{NB}_{2}$ & 23 & 99.09 & 4.33 \\
\hline & $\mathrm{MB} \mathrm{T}_{1}$ & 17 & 3.15 & 2.26 & & $\mathrm{MB} \mathrm{T}_{1}$ & 17 & 99.29 & 4.81 \\
\hline & $\mathrm{MB} \mathrm{T}_{2}$ & 17 & 3.38 & 1.98 & & $\mathrm{MB} \mathrm{T}_{2}$ & 17 & 99.53 & 5.52 \\
\hline \multirow{4}{*}{ UCl-NA } & $\mathrm{NB} \mathrm{T}_{1}$ & 23 & 5.28 & 1.66 & \multirow{4}{*}{ UCI.LCI } & $\mathrm{NB} \mathrm{T}_{1}$ & 23 & 125.7 & 7.5 \\
\hline & $\mathrm{NB} \mathrm{T}_{2}$ & 23 & 5.85 & 1.84 & & $\mathrm{NB} \mathrm{T}_{2}$ & 23 & 124.61 & 7.59 \\
\hline & $\mathrm{MB} \mathrm{T}_{1}$ & 17 & 5.56 & 1.69 & & $\mathrm{MB} \mathrm{T}_{1}$ & 17 & 121.41 & 6.44 \\
\hline & $\mathrm{MB} \mathrm{T}_{2}$ & 17 & 5.71 & 1.93 & & $\mathrm{MB} \mathrm{T}_{2}$ & 17 & 120.82 & 7.35 \\
\hline \multirow{4}{*}{ LCI-NB } & $\mathrm{NB} \mathrm{T}_{1}$ & 23 & 5.61 & 1.8 & \multirow{4}{*}{ ANB } & $\mathrm{NB} \mathrm{T}_{1}$ & 23 & 4.48 & 2.19 \\
\hline & $\mathrm{NB} \mathrm{T}_{2}$ & 23 & 6.13 & 1.53 & & $\mathrm{NB} \mathrm{T}_{2}$ & 23 & 4 & 2.15 \\
\hline & $\mathrm{MB} \mathrm{T}_{1}$ & 17 & 6.97 & 1.75 & & $\mathrm{MB} \mathrm{T}_{1}$ & 17 & 5.94 & 1.68 \\
\hline & $\mathrm{MBT}_{2}$ & 17 & 7.15 & 1.82 & & $\mathrm{MB} \mathrm{T}_{2}$ & 17 & 5.24 & 1.56 \\
\hline \multirow{4}{*}{ UCI.NA } & $N B T_{1}$ & 23 & 22.22 & 4.78 & \multirow{4}{*}{ GoGn.SN } & $\mathrm{NB}_{1}$ & 23 & 31.83 & 5.1 \\
\hline & $\mathrm{NB}_{2}$ & 23 & 22.83 & 5.27 & & $\mathrm{NB} \mathrm{T}_{2}$ & 23 & 30.7 & 5.09 \\
\hline & $M B T_{1}$ & 17 & 22.88 & 6.5 & & $M B T_{1}$ & 17 & 34.71 & 4.04 \\
\hline & $\mathrm{MB} \mathrm{T}_{2}$ & 17 & 23.82 & 6.43 & & $\mathrm{MB} \mathrm{T}_{2}$ & 17 & 33.71 & 4.57 \\
\hline \multirow{4}{*}{ LCI.NB } & $\mathrm{NB}_{1}$ & 23 & 28.09 & 4.94 & \multirow{4}{*}{ OccPI.SN } & $\mathrm{NB} \mathrm{T}_{1}$ & 23 & 16.48 & 4.83 \\
\hline & $\mathrm{NB} \mathrm{T}_{2}$ & 23 & 27.87 & 4.88 & & $\mathrm{NB} \mathrm{T}_{2}$ & 23 & 14.83 & 5.21 \\
\hline & $\mathrm{MB} \mathrm{T}_{1}$ & 17 & 29.59 & 4.09 & & $\mathrm{MB} \mathrm{T}_{1}$ & 17 & 19.12 & 2.26 \\
\hline & $\mathrm{MB} \mathrm{T}_{2}$ & 17 & 29.76 & 5.52 & & $\mathrm{MB} \mathrm{T}_{2}$ & 17 & 17.53 & 2.21 \\
\hline
\end{tabular}

Table 2 - Mean, standard deviation and p value for the variables.

\begin{tabular}{|c|c|c|c|c|c|}
\hline MEASURE & GROUP & n & MEAN & S.D. & intra and Intergroups difference \\
\hline \multirow{4}{*}{ Overjet } & $\mathrm{NB} \mathrm{T}_{1}$ & 23 & 4.21 & 2.14 & NS \\
\hline & $\mathrm{NBT}_{2}$ & 23 & 3.74 & 1.77 & ${ }^{*} \mathrm{NB} \mathrm{T}_{2} \times \mathrm{MB} \mathrm{T}_{1}$ \\
\hline & $\mathrm{MB} \mathrm{T}_{1}$ & 17 & 5.35 & 1.86 & ${ }^{*} \mathrm{NB} \mathrm{T}_{2} \times \mathrm{MB} \mathrm{T}_{1}$ \\
\hline & $\mathrm{MBT}_{2}$ & 17 & 5 & 1.7 & NS \\
\hline \multirow{4}{*}{ UCI-NA } & $\mathrm{NB} \mathrm{T}_{1}$ & 23 & 5.28 & 1.66 & ${ }^{*} N B T_{1} \times N B T_{2}$ \\
\hline & $\mathrm{NB} \mathrm{T}_{2}$ & 23 & 5.85 & 1.84 & ${ }^{*} N B T_{1} \times N B T_{2}$ \\
\hline & $\mathrm{MB} \mathrm{T}_{1}$ & 17 & 5.56 & 1.69 & NS \\
\hline & $\mathrm{MB} \mathrm{T}_{2}$ & 17 & 5.71 & 1.93 & NS \\
\hline \multirow{4}{*}{ LCI-NB } & $\mathrm{NB} \mathrm{T}_{1}$ & 23 & 5.61 & 1.8 & ${ }^{*} \mathrm{NB} T_{1} \times N B T_{2},{ }^{*} N B T_{1} \times M B T_{2}$ \\
\hline & $\mathrm{NB} \mathrm{T}_{2}$ & 23 & 6.13 & 1.53 & ${ }^{*} \mathrm{NB} T_{1} \times N B T_{2}$ \\
\hline & $M B T_{1}$ & 17 & 6.97 & 1.75 & NS \\
\hline & $\mathrm{MB} \mathrm{T}_{2}$ & 17 & 7.15 & 1.82 & ${ }^{*} \mathrm{NB} \mathrm{T}_{1} \times \mathrm{MB} \mathrm{T}_{2}$ \\
\hline \multirow{4}{*}{ ANB } & $\mathrm{NB}_{1}$ & 23 & 4.48 & 2.19 & NS \\
\hline & $\mathrm{NB} \mathrm{T}_{2}$ & 23 & 4 & 2.15 & ${ }^{* * N B T_{2}} \times \mathrm{MBT}_{1}$ \\
\hline & $\mathrm{MB} \mathrm{T}_{1}$ & 17 & 5.94 & 1.68 & ${ }^{* *} \mathrm{NB} \mathrm{T}_{2} \times \mathrm{MBT}_{1}$ \\
\hline & $\mathrm{MB} \mathrm{T}_{2}$ & 17 & 5.24 & 1.56 & NS \\
\hline \multirow{4}{*}{ GoGn.SN } & $\mathrm{NB}_{1}$ & 23 & 31.83 & 5.1 & $* * N B T_{1} \times N B T_{2}$ \\
\hline & $\mathrm{NB} \mathrm{T}_{2}$ & 23 & 30.7 & 5.09 & $* * N B T_{1} \times N B T_{2}$ \\
\hline & $\mathrm{MB} \mathrm{T}_{1}$ & 17 & 34.71 & 4.04 & NS \\
\hline & $\mathrm{MB} \mathrm{T}_{2}$ & 17 & 33.71 & 4.57 & NS \\
\hline \multirow{4}{*}{ OccPI.SN } & $\mathrm{NB} \mathrm{T}_{1}$ & 23 & 16.48 & 4.83 & $\star * \star N B T_{1} \times N B T_{2}$ \\
\hline & $\mathrm{NB} \mathrm{T}_{2}$ & 23 & 14.83 & 5.21 & ${ }^{* * *} \mathrm{NB} \mathrm{T}_{1} \times \mathrm{NB} \mathrm{T}_{2^{\prime}}{ }^{* * *} \mathrm{NB} \mathrm{T}_{2} \times \mathrm{MB} \mathrm{T}_{1}$ \\
\hline & $M B T_{1}$ & 17 & 19.12 & 2.26 & ${ }^{* * *} \mathrm{NB} \mathrm{T}_{2} \times \mathrm{MB} \mathrm{T}_{1}$ \\
\hline & $\mathrm{MB} \mathrm{T}_{2}$ & 17 & 17.53 & 2.21 & NS \\
\hline
\end{tabular}

NOTE: Significance level for Tukey HSD multiple comparisons ${ }^{*} p<0.05 ;{ }^{* *} p<0.03 ;{ }^{* * *} p<0.01$. 
balance with the buccinator muscle. It was verified an increase of the linear measures UCI-NA and LCI-NB from 10 to 16 years of age, which may be related to projection of maxillary and mandibular incisors, agreeing with Bishara. ${ }^{2}$ On the other hand, Forsberg 9 observed verticalization of the incisors with facial growth. In this research, the measurement LCI-NB presented an increase proportionally larger than UCI-NA, explained as a way to camouflage the Class II skeletal relation. It is suggested that the alteration observed in the positioning of incisors can also be explained by the action of tongue muscles. However, Baydas et $\mathrm{al}^{1}$ did not observe statistically significant difference in the positioning of these teeth during growth. From analysis of the ANB angle it was verified that there was a reduction on the difference between maxillary and mandibular bone bases in the sagittal plane, which seems to be directly related to mandibular growth and overjet alterations. The fact that the linear measurements related to the positioning of the mandibular incisor increases in larger proportion than the maxillary incisor may have caused the reduction on ANB. The respiratory pattern affected this result, where mouth breathers presented a larger ANB, disagreeing with the results of Frasson et al. ${ }^{10}$ It is suggested that the decline on the tongue rest position, affected the maxillary growth, according to Subtelny ${ }^{23}$ nasal breathing is essential for a correct growth and development of the craniofacial complex. However, Jakobsone et a ${ }^{12}$ advocate that the respiratory pattern does not affect the soft tissue profile, and that such changes depend of the craniocervical posture and age of the patients. The angular measurement GoGn.SN presented a reduction from initial to final moment. It is concluded that this reduction can be related to counterclockwise mandibular rotation, as consequent reduction of overjet and ANB, as occurred in this work. The facial growth pattern is also responsible for alterations in this measure, for individuals with tendency to horizontal growth, will present a reduced GoGn.SN, and individuals with vertical growth, an increased GoGn.SN. As all patients were in growth stage, the difference can be explained by a genetic horizontal growth pattern disagreeing with results of Lessa et al, ${ }^{14}$ which did not observe significant differences on these measures. Likewise, the measure OccPl.SN also reduced, due to reduction on the inclination of occlusal plane, consequence of the change on positioning of maxillary and mandibular incisors and the mandibular rotation. This measurement was affected by the respiratory pattern, according to Lessa et $\mathrm{al},{ }^{14}$ mouth breathers present greater mandibular inclination and vertical growth pattern. This work obtained statistically significant differences in the positioning of incisors in individuals with distinct respiratory patterns, agreeing with results by Spinelli. ${ }^{21}$ Thus, the mouth breathing affected growth of some facial structures, causing a mandibular rotation down and backwards, in relation to the palate; and reduction of angle formed by intersection of mandibular plane with nasal plane. ${ }^{13}$ According to literature, there is correlation between alterations caused by mouth breathing and the occlusion, ${ }^{13}$ fact also verified in this work. It is assumed that alterations occurred on measures were consequence of genetic growth pattern, for with aging there is a tendency of the facial profile to become relatively more straight ${ }^{28}$ associated to environmental factors, especially the respiratory method. However, this result disagree with Gwynne-Evans and Ballard; ${ }^{11}$ Tomer and Harvold, ${ }^{24}$ which indicated that muscle patterns and skeletal growth are genetically defined and, therefore, the individual characteristics, favorable or not, are inherited and little influenced by the alterations on respiratory pattern. Therefore, the alterations in positioning of incisors and the individual's respiratory pattern must be considered on the diagnosis, elaboration of treatment plan and execution of treatment in individuals in growth stage.

\section{CONCLUSION}

It is concluded that there was alteration in the positioning of incisors and overjet, during growth and with interference on the respiratory pattern. 


\section{REFERENCES}

1. Baydas B, Yavuz I, Atasaral N, Ceylan I, Dagsuyu I. Investigation of the changes in the positions of upper and lower incisors, overjet, overbite, and irregularity index in subjects with different depths of curve of Spee. Angle Orthod. 2004;74(3):349-55

2. Bishara SE. Longitudinal cephalometric standards from 5 years of age to adulthood. Am J Orthod. 1981:79(1):35-44.

3. Broadbent $\mathrm{BH}$. A new X-ray technique and its application in Orthodontics. Angle Orthod. 1931:1(2):45-6.

4. Ceylan I, Baydas B, Bolukbasi B. Longitudinal cephalometric changes in incisor position, overjet, and overbite between 10 and 14 years of age. Angle Orthod. 2002;72(3):246-50

5. Dahlberg G. Statistical methods for medical and biological students. New York: Interscience; 1940

6. Downs WB. Variation of facial relationships: their significance in treatment and prognosis. Am J Orthod. 1948;34(10):812-40

7. Ellis EE, McNamara JA. Cephalometric evaluation of incisor position. Angle Orthod. 1986:56(4):324-44

8. Fleming $\mathrm{H}$. An investigation of the vertical overbite during the eruption of the permanent dentition. Am J Orthod. 1961:31(1):53-62.

9. Forsberg CM. Facial morphology and ageing: a longitudinal cephalometric investigation of young adults. Eur J Orthod. 1979;1(1):15-23.

10. Frasson JMD, Magnani MBBA, Nouer DF, Siqueira VCV, Lunardi NC. Cephalometric study between nasal and predominantly mouth breathers. Braz J Otorhinolar. 2006;72(1):72-81.

11. Gwynne-Evans E, Ballard CF. The mouth-breather. Am J Orthod 1958:44(7):559

12. Jakobsone G, Urtane I, Terauds I. Soft tissue profile of children with impaired nasal breathing. Stomatol. 2006:8(2):39-43

13. Kerr WJS, McWilliam JS, Linder-Aronson S. Mandibular form and position related to changed mode of breathing - a five-year longitudinal study Angle Orthod. 1989:59(2):91-6

14. Lessa FCR, Enoki C, Feres MFN, Valera FCP, Lima WTA, Matsumoto MAN Influência do padrão respiratório na morfologia craniofacial. Rev Bras Otorrinolaringol. 2005;71(2):156-60
15. Mocellin M. Respirador bucal. In: Petrelli, E. Ortodontia para Fonoaudiologia. São Paulo: Lovise; 1992. p. 131-43.

16. Moyers RE. Ortodontia. 4aㅡ ed. Rio de Janeiro: Guanabara Koogan; 1991 $786 \mathrm{p}$.

17. Prahl-Andersen B, Ligthelm-Bakker AS, Wattel E, Nanda R. Adolescent growth changes in soft tissue profile. Am J Orthod Dentofacial Orthop. 1995;107(5):476-83

18. Ricketts RM. Perspectives in the clinical application of cephalometrics. Angle Orthod. 1981;51(2):115-50

19. Riedel RA. The relation of maxillary structures to cranium in malocclusion and in normal occlusion. Angle Orthod. 1952:22(3):142-5.

20. Russouw PE, Preston CB, Lombard CJ, Truter JW. A longitudinal evaluation of the anterior border of the dentition. Am J Orthod Dentofacial Orthop. 1993:104(2):146-152.

21. Spinelli MLM, Casanova PC. Respiração bucal. [acesso em 2002 Fev 2] Disponivel em: www.odontologia.com.br/artigos

22. Steiner CC. Cephalometrics for you and me. Am J Orthod. 1953;39(10):729-55

23. Subtelny JD. Oral respiration: facial mal development and corrective dentofacial orthopedics. Angle Orthod. 1980;50(3):147-64.

24. Tomer BS, Harvold EP. Primate experiments on mandibular growth direction. Am J Orthod. 1982;82(2):114-9

25. Tweed $\mathrm{CH}$. The Frankfurt-mandibular incisor angle (FMIA) in orthodontic diagnosis, treatment planning and prognosis. Angle Orthod. 1954:24(3):121-69

26. Tweed CH. Clinical orthodontics. St. Louis: CV Mosby; 1966. v. 1.

27. Wieler WJ, Barros AM, Barros LA, Camargo EL, Ignácio SA, Maruo H, et al. Combined protocol to aid diagnosis of breathing mode. Rev Clín Pesq Odontol. 2007:3(2):101-11

28. Zylinski CG, Nanda RS, Kapila S. Analysis of soft tissue facial profile in white males. Am J Orthod Dentofacial Orthop. 1992:101(6):514-8. 